\title{
STUDIES ON THE IMMUNE RESPONSE OF THE RHEUMATIC SUB- JECT AND ITS RELATIONSHIP TO ACTIVITY OF THE RHEU- MATIC PROCESS. IV. CHARACTERISTICS OF STRAINS OF HEMOLYTIC STREPTOCOCCUS, EFFECTIVE AND NON- EFFECTIVE IN INITIATING RHEUMATIC ACTIVITY ${ }^{1}$
}

\section{By ALVIN F. COBURN AND RUTH H. PAULI}

(From the Department of Medicine, College of Physicians and Surgeons, Columbia University,
and the Presbyterian Hospital, New York City)

(Received for publication June 28, 1935)

The authors have reported (1) certain biological characteristics of strains of hemolytic streptococcus associated with pharyngeal infection, which appeared to reactivate the rheumatic process in individuals previously stigmatized with the disease. These organisms were in most instances Streptococcus pyogenes, according to Holman's classification; they produced skin toxin neutralizable by antiscarlatinal serum; they fell into six serological groups, and were indistinguishable from strains obtained from upper respiratory tract infection of non-rheumatic subjects. These studies also indicated that in many instances, perhaps 20 to 40 per cent, hemolytic streptococcus infection in individuals recognized to be rheumatic subjects is not followed by any clinical evidence of rheumatic activity. The failure of these patients to develop recrudescences suggested at least two possibilities: one, ineffectiveness of the strain; two, a refractory state of the host. The purpose of the present study was to determine, so far as possible with methods available, whether there are any demonstrable differences between those pathogenic agents which are effective and those which are non-effective in reactivating the rheumatic process.

Forty strains collected from 38 individuals comprise the material for the present study. These organisms were selected from individuals who had had at least one attack of rheumatic fever, who had been under close observation for a period of two to six years, who did not appear to be carriers of hemolytic streptococcus, who had been free of all clinical evidence of rheumatic activity for at least six months, and who con-

\footnotetext{
1 The work reported in this communication was carried out under The W. K. Kellogg Foundation.
}

tracted, while being studied, a frank pharyngitis associated with the appearance of hemolytic streptococcus predominating in the throat flora. All of these infections occurred in the winter or spring months, ${ }^{2}$ and the possibility of a rheumatic recrudescence was expected in each instance. Half of the individuals developed severe attacks of rheumatic fever. The organisms isolated from these patients at the time of pharyngitis are considered effective and are designated " $E$." In the other half, the rheumatic process appeared to remain quiescent, insofar as it was possible to determine with the methods now available. ${ }^{3}$ The organisms isolated from the latter patients at the time of pharyngitis ${ }^{4}$ were considered ineffective in initiating rheumatic activity and are designated "NE."

One of the first possible reasons to consider for the ineffectiveness of certain strains was that they might be of animal origin. Animal strains, as Lancefield (2) has demonstrated, show good

2 The authors have observed that in New York City the hemolytic streptococcus throat infections occurring in the spring months have been more effective in initiating rheumatic activity than those in other seasons. A study of the toxin production of thirty strains of hemolytic streptococcus showed that of seven strains associated with fall infections, only one was a strong toxin producer whereas in the spring infections, about half of the organisms were strong toxin producers. This observation suggests the possibility that in New York City there may be a seasonal variation in the capacity of hemolytic streptococcus to produce soluble toxin as well as a seasonal variation in the incidence of these infections.

3 These subjects were kept under close clinical and laboratory observation on the wards and in the out-patient department of the Presbyterian Hospital.

4 These attacks of pharyngitis were well defined and in general more severe than those associated with the " $E$ " infections. 
agreement between their biochemical and cultural characteristics, and their serological classification. Therefore, a study of these biochemical characteristics was undertaken, to determine whether these strains were of animal or human type.

\section{TECHNIQUE}

All cultures were seeded with $0.1 \mathrm{cc}$. of a 16 hour growth of the strain in phosphate neopeptone broth. Controls used throughout this work consisted of one strain known to give a positive, one strain known to give a negative reaction and also a tube of the medium inoculated with $0.1 \mathrm{cc}$. of sterile seed culture broth. The controls were incubated with the strains being tested. All of the organisms were beta hemolytic strains which caused marked hemolysis of rabbit red blood cells when grown on plates of blood agar or in tubes of blood broth.

The colony type was determined by the appearance on chocolate blood agar plates, following Todd's (3) technique. The plates were examined with a hand lens after
24 hours' growth, and the types were recorded as matt or glossy.

The method of Avery and Cullen (4) was used for determination of $\mathrm{pH}$. Readings were made on the fourth day of cultures grown in 1 per cent dextrose broth. Brom cresol purple, methyl red and phenol red were used as indicators.

Fermentation reactions on trehalose and sorbitol were observed at the end of one week's incubation, according to the method of Edwards (5). All tubes were cultured to be sure of the presence of living organisms.

Reduction of methylene blue was tested with the method used by R. C. Avery (6). Readings were made daily for one week, and the final reading recorded.

Hydrolysis of sodium hippurate was tested as advocated by Ayers and Rupp (7). The reaction was considered negative when the hippurate and protein precipitates found at first were redissolved in ferric chloride leaving a clear solution.

From Table $\mathrm{I}$ it is seen that the $\mathrm{pH}$ of all strains falls between 5.1 and 5.7 ; that all ferment

TABLE I

Biological and cultural characteristics of strains of hemolytic streptococcus isolated from the throats of rheumatic subjects during acute pharyngitis-E followed by acute rheumatism; $N E$ followed by good health

\begin{tabular}{|c|c|c|c|c|c|c|c|c|c|c|c|c|c|c|c|c|}
\hline \multirow{2}{*}{ Strain } & \multirow{2}{*}{$\begin{array}{l}\text { Col- } \\
\text { ony } \\
\text { type }\end{array}$} & \multirow{2}{*}{$\begin{array}{l}\text { pH } \\
\text { in } \\
\text { dex- } \\
\text { trose } \\
\text { broth }\end{array}$} & \multicolumn{2}{|c|}{ Fermentation of } & \multirow{2}{*}{$\begin{array}{c}\text { Methyl- } \\
\text { ene } \\
\text { blue } \\
\text { toler- } \\
\text { ance }\end{array}$} & \multirow{2}{*}{$\begin{array}{c}\text { Hydroly- } \\
\text { sis of } \\
\text { sodium } \\
\text { hip- } \\
\text { purate }\end{array}$} & \multicolumn{3}{|c|}{$\begin{array}{c}\text { Fermentation } \\
\text { of } \\
\text { sugars }\end{array}$} & \multirow{2}{*}{$\begin{array}{l}\text { Sugar fer- } \\
\text { mentation } \\
\text { type }\end{array}$} & \multicolumn{4}{|c|}{ Enzyme production } & \multirow{2}{*}{$\begin{array}{l}\text { Strep- } \\
\text { tolysin } \\
\text { produc- } \\
\text { tion* }\end{array}$} & \multirow{2}{*}{$\begin{array}{l}\text { Erythro- } \\
\text { genic } \\
\text { toxin } \\
\text { produc- } \\
\text { tion }\end{array}$} \\
\hline & & & $\begin{array}{l}\text { Sor- } \\
\text { bitol }\end{array}$ & $\begin{array}{c}\text { Tre- } \\
\text { halose }\end{array}$ & & & $\begin{array}{l}\text { Lac- } \\
\text { tose }\end{array}$ & $\begin{array}{c}\text { Man- } \\
\text { nite }\end{array}$ & $\begin{array}{c}\text { Sali- } \\
\text { cin }\end{array}$ & & $\begin{array}{c}\text { Lique- } \\
\text { faction } \\
\text { of } \\
\text { gelatin }\end{array}$ & $\begin{array}{l}\text { Diges } \\
\text { tion } \\
\text { of } \\
\text { casein }\end{array}$ & $\begin{array}{l}\text { Histase } \\
\text { activity }\end{array}$ & $\begin{array}{l}\text { Fibrinoly- } \\
\text { tic activity }\end{array}$ & & \\
\hline 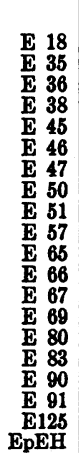 & $\begin{array}{l}\text { Matt } \\
\text { Matt } \\
\text { Matt } \\
\text { Matt } \\
\text { Matt } \\
\text { Matt } \\
\text { Matt } \\
\text { Matt } \\
\text { Matt } \\
\text { Matt } \\
\text { Matt } \\
\text { Matt } \\
\text { Matt } \\
\text { Matt } \\
\text { Matt } \\
\text { Matt } \\
\text { Matt } \\
\text { Matt } \\
\text { Matt } \\
\text { Matt }\end{array}$ & $\begin{array}{l}5.3 \\
5.4 \\
5.3 \\
5.3 \\
5.1 \\
5.3 \\
5.3 \\
5.7 \\
5.6 \\
5.3 \\
5.1 \\
5.3 \\
5.3 \\
5.3 \\
5.5 \\
5.1 \\
5.3 \\
5.3 \\
5.2 \\
5.4\end{array}$ & $\begin{array}{l}\bar{z} \\
\bar{z} \\
\bar{z} \\
\bar{z} \\
\bar{z} \\
\bar{z} \\
\bar{z} \\
\bar{z} \\
\bar{z}\end{array}$ & $\begin{array}{l}+ \\
+ \\
+ \\
+ \\
+ \\
+ \\
+ \\
+ \\
+ \\
+ \\
+ \\
+ \\
+ \\
+ \\
+ \\
+\end{array}$ & $\begin{array}{l}\bar{z} \\
\bar{z} \\
\bar{z} \\
\bar{z} \\
\bar{z} \\
\bar{z} \\
\bar{z} \\
\bar{z} \\
\bar{z} \\
\overline{-}\end{array}$ & $\begin{array}{l}\bar{z} \\
\bar{z} \\
\bar{z} \\
\bar{z} \\
\bar{z} \\
\bar{z} \\
\bar{z} \\
\bar{z} \\
\bar{z}\end{array}$ & $\begin{array}{l}+ \\
+ \\
+ \\
+ \\
\dot{t} \\
+ \\
+ \\
+ \\
\pm \\
+ \\
+ \\
+ \\
+ \\
+\end{array}$ & $\begin{array}{l}\bar{z} \\
\bar{z} \\
\bar{t} \\
\bar{z} \\
\bar{z} \\
\bar{z} \\
\bar{z} \\
\bar{z} \\
\bar{t}\end{array}$ & $\begin{array}{l}+ \\
+ \\
+ \\
+ \\
+ \\
+ \\
+ \\
+ \\
+ \\
+ \\
+ \\
+ \\
+ \\
+ \\
+\end{array}$ & $\begin{array}{l}\text { Pyogenes } \\
\text { Pyogenes } \\
\text { Infrequens } \\
\text { Pyogenes } \\
\text { Equi } \\
\text { Hemolytic II } \\
\text { Equi } \\
\text { Pyogenes } \\
\text { Pyogenes } \\
\text { Pyogenes } \\
\text { Pyogenes } \\
\text { Pyogenes } \\
\text { Pyogenes } \\
\text { Equi } \\
\text { Pyogenes } \\
\text { Pyogenes } \\
\text { Pyogenes } \\
\text { Pyogenes } \\
\text { Infrequens } \\
\text { Pyogenes }\end{array}$ & $\begin{array}{l}\bar{z} \\
\bar{z} \\
\bar{z} \\
\bar{z} \\
\bar{z} \\
\bar{z} \\
\bar{z} \\
\bar{z} \\
\bar{z}\end{array}$ & $\begin{array}{l}\bar{z} \\
\dot{+} \\
\pm \\
\bar{t} \\
\pm \\
\pm \\
\pm \\
+ \\
\pm \\
\pm \\
\bar{t} \\
\dot{+} \\
\pm \\
\pm\end{array}$ & $\begin{array}{l}\text { Weak } \\
\text { Weak } \\
\text { Weak } \\
\text { Weak } \\
\text { Negative } \\
\text { Moderate } \\
\text { Weak } \\
\text { Weak } \\
\text { Moderate } \\
\text { Strong } \\
\text { Weak } \\
\text { Strong } \\
\text { Weak } \\
\text { Weak } \\
\text { Negative } \\
\text { Weak } \\
\text { Strong } \\
\text { Weak } \\
\text { Negative } \\
\text { Moderate }\end{array}$ & & $\begin{array}{c}c c . \\
.000120 \\
.000008 \\
.000008 \\
.000024 \\
.000008 \\
+* \\
.000008 \\
.000030 \\
.000020 \\
.000008 \\
.000008 \\
.000020 \\
.000020 \\
.000004 \\
.000008 \\
.000008 \\
.000020 \\
.000004 \\
.000008\end{array}$ & $\begin{array}{l}\text { Strong } \\
\text { Strong } \\
\text { Strong } \\
\text { Strong } \\
\text { Strong } \\
\text { Negative } \\
\text { Strong } \\
\text { Strong } \\
\text { Weak } \\
\text { Strong } \\
\text { Strong } \\
\text { Weak } \\
\text { Strong } \\
\text { Strong } \\
\text { Strong } \\
\text { Strong } \\
\text { Strong } \\
\text { Strong } \\
\text { Strong } \\
\text { Strong }\end{array}$ \\
\hline $\begin{array}{rr}\text { NE } & 1 \\
N \mathrm{NE} & 2 \\
\mathrm{NE} & 4 \\
\mathrm{NE} & 5 \\
\mathrm{NE} & 6 \\
\mathrm{NE} & 7 \\
\mathrm{NE} & 8 \\
\mathrm{NE} & 9 \\
\mathrm{NE} & 10 \\
\mathrm{NE} & 11 \\
\mathrm{NE} & 12 \\
\mathrm{NE} & 13 \\
\mathrm{NE} & 14 \\
\mathrm{NE} & 15 \\
\mathrm{NE} & 16 \\
\mathrm{NE} & 17 \\
\mathrm{NE} & 18 \\
\mathrm{NE} & 19 \\
\mathrm{NE} & 20 \\
\mathrm{NE} & 21\end{array}$ & $\begin{array}{l}\text { Glossy } \\
\text { Matt } \\
\text { Glossy } \\
\text { Matt } \\
\text { Matt } \\
\text { Matt } \\
\text { Glossy } \\
\text { Glossy } \\
\text { Matt } \\
\text { Matt } \\
\text { Matt } \\
\text { Matt } \\
\text { Matt } \\
\text { Matt } \\
\text { Matt } \\
\text { Matt } \\
\text { Matt } \\
\text { Matt } \\
\text { Matt } \\
\text { Matt }\end{array}$ & $\begin{array}{l}5.3 \\
5.7 \\
5.8 \\
5.3 \\
5.2 \\
5.3 \\
5.1 \\
5.3 \\
5.2 \\
5.1 \\
5.6 \\
5.3 \\
5.3 \\
5.1 \\
5.1 \\
\mathbf{5 . 2} \\
5.1 \\
\mathbf{5 . 1} \\
\mathbf{5 . 2} \\
\mathbf{5 . 2}\end{array}$ & $\begin{array}{l}\bar{z} \\
\bar{z} \\
\bar{z} \\
\bar{z} \\
\bar{z} \\
\bar{z} \\
\bar{z} \\
\bar{z} \\
\bar{z}\end{array}$ & $\begin{array}{l}+ \\
+ \\
+ \\
+ \\
+ \\
+ \\
+ \\
+ \\
+ \\
+ \\
+ \\
+ \\
+ \\
+ \\
+\end{array}$ & $\begin{array}{l}\bar{z} \\
\bar{z} \\
\bar{z} \\
\bar{z} \\
\bar{z} \\
\bar{z} \\
\bar{z} \\
\bar{z} \\
\bar{z}\end{array}$ & $\begin{array}{l}\bar{z} \\
\bar{z} \\
\bar{z} \\
\bar{z} \\
\bar{z} \\
\bar{z} \\
\bar{z} \\
\bar{z} \\
\overline{-}\end{array}$ & $\begin{array}{l}\overline{+} \\
+ \\
+ \\
+ \\
\frac{+}{+} \\
\frac{+}{+} \\
+ \\
+ \\
+ \\
+ \\
+ \\
+ \\
+\end{array}$ & $\begin{array}{l}\bar{z} \\
\bar{z} \\
\bar{z} \\
\bar{z} \\
\bar{z} \\
\bar{z} \\
\bar{z} \\
\bar{z}\end{array}$ & $\begin{array}{l}z \\
\bar{t} \\
+ \\
+ \\
\pm \\
+ \\
+ \\
+ \\
+ \\
+ \\
+ \\
+ \\
+ \\
+\end{array}$ & $\begin{array}{l}\text { Subacidus } \\
\text { Anginosus } \\
\text { Anginosus } \\
\text { Pyogenes } \\
\text { Pyogenes } \\
\text { Pyogenes } \\
\text { Equi } \\
\text { Anginosus } \\
\text { Pyogenes } \\
\text { Equi } \\
\text { Pyogenes } \\
\text { Pyogenes } \\
\text { Pyogenes } \\
\text { Infrequens } \\
\text { Pyogenes } \\
\text { Equi } \\
\text { Pyogenes } \\
\text { Equi } \\
\text { Pyogenes } \\
\text { Pyogenes }\end{array}$ & $\begin{array}{l}\bar{z} \\
\bar{z} \\
\bar{z} \\
\bar{z} \\
\bar{z} \\
\bar{z} \\
\bar{z} \\
\bar{z} \\
\bar{z}\end{array}$ & 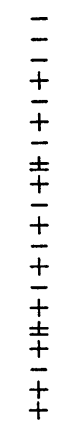 & $\begin{array}{l}\text { Weak } \\
\text { Weak } \\
\text { Weak } \\
\text { Weak } \\
\text { Weak } \\
\text { Weak } \\
\text { Weak } \\
\text { Weak } \\
\text { Weak } \\
\text { Weak } \\
\text { Moderate } \\
\text { Weak } \\
\text { Weak } \\
\text { Weak } \\
\text { Weak } \\
\text { Weak } \\
\text { Negative } \\
\text { Negative } \\
\text { Weak } \\
\text { Weak }\end{array}$ & & $\begin{array}{c}* * \\
* * \\
.000004 \\
* * \\
* * \\
.000004 \\
* * \\
.000004 \\
.000050 \\
.000024 \\
* * \\
* * \\
.000004 \\
* * \\
* * \\
.000004 \\
* * \\
* *\end{array}$ & $\begin{array}{l}\text { Weak } \\
\text { Negative } \\
\text { Negative } \\
\text { Negative } \\
\text { Strong } \\
\text { Negative } \\
\text { Negative } \\
\text { Negative } \\
\text { Negative } \\
\text { Negative } \\
\text { Negative } \\
\text { Weak } \\
\text { Negative } \\
\text { Strong } \\
\text { Weak } \\
\text { Strong } \\
\text { Strong } \\
\text { Negative } \\
\text { Negative } \\
\text { Negative }\end{array}$ \\
\hline
\end{tabular}

* Volume of Todd's globulin required to neutralize 1 M.H.D. of streptolysin.

** Streptolysin titer too weak to be determined. 
trehalose; that none ferment sorbitol; that only one, or possibly two, reduce methylene blue; that none hydrolyze sodium hippurate. These findings indicate (see Lancefield (2)) that all the strains in both the $\mathrm{E}$ group and the NE group are of the human type.

Previous studies (1) have shown that 20 out of 27 strains of organisms associated with acute rheumatism were of the Streptococcus pyogenes group (8); that is, they fermented lactose and salicin but not mannite. In order to determine whether these characters were of any significance in determining the effectiveness of a strain in reactivating the rheumatic process, these same fermentation reactions were tested with $E$ and $\mathrm{NE}$ strains and also with 33 strains obtained during the same period of time from non-rheumatic subjects with acute pharyngitis. The results of the test on rheumatic subjects, detailed in Table I, are summarized, along with the data on nonrheumatic controls, in Table II. There was no

TABLE II

Types of hemolytic streptococcus obtained from cases of pharyngitis in rheumatic and non-rheumatic subjects

\begin{tabular}{|c|c|c|c|c|c|c|c|c|}
\hline $\begin{array}{l}\text { Source of } \\
\text { organism }\end{array}$ & $\begin{array}{l}\text { Pyo- } \\
\text { genes }\end{array}$ & Equi & $\begin{array}{c}\text { Hemo- } \\
\text { lytic III }\end{array}$ & $\begin{array}{l}\text { Infro- } \\
\text { quens }\end{array}$ & $\begin{array}{l}\text { Angi- } \\
\text { nosus }\end{array}$ & $\begin{array}{l}\text { Hemo- } \\
\text { lytic II }\end{array}$ & $\begin{array}{l}\text { Hemo- } \\
\text { lytic I }\end{array}$ & \begin{tabular}{|} 
Sub- \\
acidus
\end{tabular} \\
\hline $\begin{array}{l}\text { Rheumatic } \\
\text { subjects: } \\
\text { E strains. } \\
\text { NE strains. } \\
\text { Non-rheuma- } \\
\text { tic subjects. }\end{array}$ & $\begin{array}{l}14 \\
11 \\
20\end{array}$ & $\begin{array}{l}3 \\
4 \\
6\end{array}$ & 2 & $\begin{array}{l}2 \\
1 \\
2\end{array}$ & 1 & $\begin{array}{l}1 \\
1\end{array}$ & 1 & 1 \\
\hline
\end{tabular}

significant difference in any of the three groups of organisms. During this period of study Streptococcus pyogenes has been the prevalent variety associated with throat infections in New York City.

Another series of tests was undertaken to determine whether there are differences in the capacity of the two groups ( $E$ and $N E$ ) to digest proteins. The liquefaction of gelatine, hydrolysis of casein, tissue digestion by histase, and plasma clot dissolution by fibrinolysin $(9,10)$ were investigated.

Technique-gelatin digestion. The organisms were grown in 10 per cent gelatin for seven days at room temperature and liquefaction was sought but in no instance observed.
Casein digestion. Plates were made with 1 cc. sterile milk being added to $12 \mathrm{cc}$. agar $\mathrm{pH} 7.4$. Three heavy inoculations from 16 hour old colonies were streaked across the surface of a plate which was then incubated for 72 hours at $37^{\circ} \mathrm{C}$. The plates were flooded with 12 per cent acetic acid and digestion indicated by the appearance of a permanent clear zone around the colonies. One plate was used for each strain tested.

Tissue-digesting enzyme. Histase detection was made according to Holman's (11) modification of Robertson's cooked-meat medium. Digestion was determined by observing the subsidence of meat in the tubes. Readings were made according to Frobisher (12) after 5 days in the incubator at $37^{\circ} \mathrm{C}$. The amount of digestion was measured in millimeters.

Fibrinolysin. The method of Tillett and Garner (9) was followed. The material used consisted of $0.2 \mathrm{cc}$. of fresh plasma from one individual (previously determined to be readily dissolved by fibrinolysin), 0.8 cc. saline, 0.5 cc. filtrate of organism tested, $0.25 \mathrm{cc}$. of a 0.25 per cent solution of $\mathrm{CaCl}_{2}$ in 0.85 per cent saline. The tubes were incubated in a water bath at $37^{\circ} \mathrm{C}$. Complete dissolution in less than 30 minutes is recorded as ++++ fibrinolytic activity; 30 to 60 minutes, +++ ; one to four hours, $++; 4$ to 24 hours, + ; incomplete dissolution in 24 hours, - .

The results are to be found in Table $I$. No significant differences in enzyme production were found between the two groups. Both failed to liquefy gelatin; a few of each group digested casein; histase production seemed perhaps more marked among a few E strains; and many strains of each group were strong in fibrinolytic activity. ${ }^{5}$

Streptolysin production. The forty organisms under investigation were tested in this laboratory for streptolysin production. In addition, nine organisms isolated from the throats of rheumatic subjects in New York were tested in England by Dr. Todd. His findings are presented in Table III.

Technique for determining streptolysin productions. The material and technique was identical with that described for making and titrating streptolysin in the first paper of this series (27). The

$\checkmark$ Sera from these patients were tested for antifibrinolysin according to the method of Tillett and Garner (9). Four groups were studied: rheumatic subjects infected with $E$ strains; rheumatic subjects infected with $\mathrm{NE}$ strains; patients with acute rheumatism, the infectious agent being undetermined; non-rheumatic subjects convalescing from proven hemolytic streptococcus infections. No significant differences were found. The results were in accord with the recent observations of Hadfield et al. (28) and Myers et al. (29). 
TABLE III

Hemolytic titers and volumes of antistreptolysin required to neutralize 1 M.H.D. as determined by Doctor Todd

\begin{tabular}{|c|c|c|c|c|c|}
\hline \multirow{2}{*}{$\begin{array}{l}\text { Strains from } \\
\text { hemolytic } \\
\text { strepto- } \\
\text { coccus } \\
\text { pharyngitis }\end{array}$} & \multirow{2}{*}{$\begin{array}{l}\text { Charac- } \\
\text { ter of } \\
\text { rheu- } \\
\text { matic } \\
\text { attack }\end{array}$} & \multirow{2}{*}{$\underset{\text { fil- }}{\mathbf{p H} \text { of }}$} & \multicolumn{2}{|c|}{ Hemolytic titer } & \multirow{2}{*}{$\begin{array}{l}\text { Volume of anti- } \\
\text { streptolysin re- } \\
\text { quired to neu- } \\
\text { tralize } 1 \text { M.H.D. } \\
\text { of hemolysin }\end{array}$} \\
\hline & & & $\begin{array}{c}\text { Com- } \\
\text { plete } \\
\text { hemo- } \\
\text { lysis }\end{array}$ & $\begin{array}{c}\text { Par- } \\
\text { tial } \\
\text { hemo- } \\
\text { lysis }\end{array}$ & \\
\hline $\begin{array}{r}\text { E } 65 \ldots \ldots \\
\text { E } 67 \ldots \ldots \\
\text { E } 69 \ldots \ldots \\
\text { E } 64 \ldots \ldots \\
\text { E } 80 \ldots \ldots \\
\text { E } 84 \ldots \ldots \\
\text { NE } 25 \ldots \ldots \\
\text { NE } 26 \ldots . . \\
\text { NE } 27 \ldots \ldots\end{array}$ & $\begin{array}{l}\text { Severe } \\
\text { Severe } \\
\text { Severe } \\
\text { Mild } \\
\text { Mild } \\
\text { Mild } \\
\text { None } \\
\text { None } \\
\text { None }\end{array}$ & $\begin{array}{l}6.6 \\
6.7 \\
7.1 \\
6.8 \\
7.0 \\
7.0 \\
5.6 \\
7.0 \\
7.9\end{array}$ & $\begin{array}{c}c c . \\
5.0 \\
1.0 \\
1.0 \\
2.0 \\
1.0 \\
0.5 \\
\text { None } \\
\text { None } \\
\text { None }\end{array}$ & $\begin{array}{c}c c . \\
0.50 \\
0.05 \\
0.05 \\
0.05 \\
0.05 \\
0.02 \\
\text { None } \\
\text { None } \\
\text { None }\end{array}$ & $\begin{array}{c}c c . \\
0.00003 \\
0.00003 \\
0.00004 \\
0.00004 \\
0.00005 \\
0.00005\end{array}$ \\
\hline
\end{tabular}

TABLE IV

Sample arrangement of tubes $\dagger$

\begin{tabular}{|c|c|c|c|c|c|c|c|c|c|c|}
\hline \multirow{2}{*}{ Strain } & \multicolumn{10}{|c|}{ Hemolytic power * } \\
\hline & 2 & 1 & .7 & & .5 & .4 & .3 & .2 & .1 & .05 \\
\hline 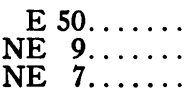 & $\underline{\mathrm{VM}}$ & $\begin{array}{l}\mathrm{C} \\
\mathrm{M} \\
\end{array}$ & $\mathrm{C}$ & & $\begin{array}{l}\mathrm{C} \\
\mathrm{S} \\
-\end{array}$ & $\stackrel{? \mathrm{C}}{\mathrm{S}}$ & $\begin{array}{l}\text { ?C } \\
\mathrm{VS} \\
-\end{array}$ & $\begin{array}{l}? \mathrm{C} \\
\text { VS } \\
-\end{array}$ & $\frac{? \mathrm{C}}{-}$ & $\frac{\text { VM }}{-}$ \\
\hline \multirow[t]{2}{*}{$\begin{array}{l}\text { Contents } \\
\text { of tubes }\end{array}$} & \multicolumn{10}{|c|}{$\begin{array}{l}\text { Lysins } 2 \text { cc., } 1 \text { cc., etc. } \\
\text { Cells } 0.5 \text { cc. }\end{array}$} \\
\hline & \multicolumn{10}{|c|}{ Combining power } \\
\hline $\begin{array}{ll}\text { E } & 50 \ldots \\
\text { NE } & 9 \ldots \\
\text { NE } & 7 \ldots\end{array}$ & - & $\underline{\mathrm{C}}$ & $\mathrm{V}$ & & - & - & - & - & - & - \\
\hline $\begin{array}{c}\text { Contents } \\
\text { of } \\
\text { tubes }\end{array}$ & \multicolumn{10}{|c|}{$\begin{array}{l}\text { Globulin } 1 / 20,000 \text { dose }=1 \mathrm{cc} \text {. in each tube } \\
\text { Lysin } 2 \mathrm{cc}, 1 \mathrm{cc} \text {., etc. } \\
\text { Cells } 0.5 \mathrm{cc} \text {. }\end{array}$} \\
\hline & \multicolumn{10}{|c|}{ Antistreptolysin required } \\
\hline Strain & 1 & .9 & .8 & .7 & .6 & .5 & .4 & .3 & .2 & .1 \\
\hline $\begin{array}{lr}\text { E } & 50 \ldots \ldots \\
\text { NE } & 9 \ldots \ldots \ldots \\
\text { NE } & 7 \ldots \ldots \ldots\end{array}$ & 二 & 二 & - & - & $\frac{\text { VS }}{-}$ & - & M & $\frac{\mathrm{VM}}{-}$ & $\frac{? C}{-}$ & C \\
\hline $\begin{array}{l}\text { Contents } \\
\text { of } \\
\text { tubes }\end{array}$ & \multicolumn{10}{|c|}{$\begin{array}{c}\text { Globulin } 1 \text { in } 10,000=1 \mathrm{cc}, 0.9 \mathrm{cc} \text {., etc. } \\
\text { Lysin undiluted } 0.5 \mathrm{cc} \text {. in each tube } \\
\text { Cells } 0.5 \mathrm{cc} \text {. }\end{array}$} \\
\hline
\end{tabular}

${ }^{*} \mathrm{C}=$ complete; $\mathrm{VM}=$ very marked; $\mathrm{M}=$ marked; $\mathrm{S}=$ slight; $\mathrm{VS}=$ very slight $;-=$ none.

$\dagger$ All tubes containing less than $2 \mathrm{cc}$. are brought up to 2 cc. volume with .85 per cent saline. hemolytic power, the combining power and the antistreptolysin necessary for neutralization were determined. The tubes were set up as in the sample tabulations in Table IV.

The results of the tests on the forty strains are to be found in Table I. It is seen that streptolysin production in glucose bicarbonate broth occurred both with $\mathrm{E}$ and $\mathrm{NE}$ organisms. However, this activity was more marked in the group of $\mathrm{E}$ strains. All but two of these organisms produced strong lysins. This was in accord with the findings of Todd (13). Only seven of the NE strains produced strong lysins; in the remaining thirteen the streptolysins were too weak for serological examination.

The capacity of these organisms to produce streptolysin in man was tested by determining the antistreptolysin titers in patients infected with these $\mathrm{E}$ and $\mathrm{NE}$ strains. In 25 members of this group it was possible to obtain blood serum just before or at the onset of pharyngitis and to make serial examinations during the two months after infection. The maximum antistreptolysin titers reached by the individuals infected with $E$ and $\mathrm{NE}$ strains are presented in Table $\mathrm{V}$, along with the organisms' streptolysin titers in glucose bicarbonate broth.

The findings in these 25 patients, divided into two classes, may be seen in Table V. All of the " $E$ " infections were followed by striking increases in the patients' antistreptolysin titers. None of the " $\mathrm{NE}$ " infections were followed by more than a slight rise in titer level. The difference between the mean $\Delta \log u$ of the $\mathrm{E}$ group and the mean $\Delta \log u$ of the NE group is 0.74 minus $0.06=0.68$, with a probable error of 0.074 . The difference between the two means is therefore 9.2 times its probable error $\left(\frac{0.68}{0.074}=9.2\right)$. This shows that the increase of titer in the $E$ group is significantly greater than that in the NE group. The marked change in antistreptolysin level of the first class of patients may be attributed to the strong streptolysin production of the infecting organisms. The slight change in antistreptolysin level of the second class may be attributed to the weak streptolysin production of most of the infecting strains. However, in four cases the streptolysin production (in vitro) of the 
TABLE V

Change in antistreptolysin titer following pharyngitis with $E$ and $N E$ strains of hemolytic streptococcus

\begin{tabular}{|c|c|c|c|c|c|c|c|}
\hline \multirow{2}{*}{ Patient } & \multirow{2}{*}{ Organism } & \multirow{2}{*}{$\begin{array}{l}\text { Streptolysin titer of culture } \\
\text { filtrate (amount of Todd's } \\
\text { antistreptolysin required } \\
\text { to neutralize } 1 \mathrm{M} \text {.H.D. } \\
\text { of streptolysin) }\end{array}$} & \multicolumn{2}{|c|}{$\begin{array}{l}\text { Antistreptolysin titer } \\
\text { of patient }\end{array}$} & \multicolumn{3}{|c|}{$\begin{array}{l}\text { Logarithm of } \\
\text { titer }=\log u\end{array}$} \\
\hline & & & $\begin{array}{l}\text { At time of } \\
\text { infection }\end{array}$ & $\begin{array}{l}\text { Following } \\
\text { infection }\end{array}$ & $\begin{array}{l}\text { At time of } \\
\text { infection }\end{array}$ & $\begin{array}{c}\text { Following } \\
\text { infection }\end{array}$ & $\Delta \log u$ \\
\hline \multirow[t]{2}{*}{ 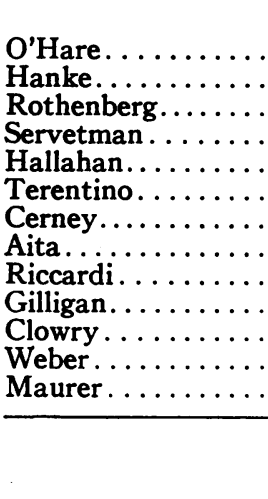 } & $\begin{array}{r}\text { E 35 } \\
\text { E 38 } \\
\text { E 45 } \\
\text { E 47 } \\
\text { Ep EH } \\
\text { E 50 } \\
\text { E 51 } \\
\text { E 65 } \\
\text { E 67 } \\
\text { E 69 } \\
\text { E 80 } \\
\text { E 90 } \\
\text { E } 125\end{array}$ & $\begin{array}{c}c c . \\
.000008 \\
.000024 \\
.000008 \\
.000008 \\
.000008 \\
.000030 \\
.000020 \\
.000008 \\
.000020 \\
.000020 \\
.000004 \\
.000008 \\
.000004\end{array}$ & $\begin{array}{r}\text { units } \\
50 \\
50 \\
333 \\
33 \\
200 \\
166 \\
33 \\
14 \\
83 \\
33 \\
125 \\
166 \\
250\end{array}$ & $\begin{array}{r}\text { units } \\
333 \\
200 \\
500 \\
250 \\
1250 \\
500 \\
1250 \\
125 \\
250 \\
333 \\
500 \\
250 \\
2500\end{array}$ & $\begin{array}{l}1.70 \\
1.70 \\
2.52 \\
1.52 \\
2.30 \\
2.22 \\
1.52 \\
1.16 \\
1.92 \\
1.52 \\
2.10 \\
2.22 \\
2.40\end{array}$ & $\begin{array}{l}2.52 \\
2.30 \\
2.70 \\
2.40 \\
3.10 \\
2.70 \\
3.10 \\
2.10 \\
2.40 \\
2.52 \\
2.70 \\
2.40 \\
3.40\end{array}$ & $\begin{array}{r}.82 \\
.60 \\
.22 \\
.88 \\
.80 \\
.48 \\
1.58 \\
.94 \\
.48 \\
1.00 \\
.60 \\
.22 \\
1.00\end{array}$ \\
\hline & & & $\begin{array}{c}100 \\
\text { (median) }\end{array}$ & $\begin{array}{c}333 \\
\text { (median) }\end{array}$ & $\begin{array}{c}1.91 \\
\text { (mean) }\end{array}$ & $\begin{array}{c}2.64 \\
\text { (mean) }\end{array}$ & $\underset{\text { (mean) }}{+.74}$ \\
\hline \multirow[t]{2}{*}{ 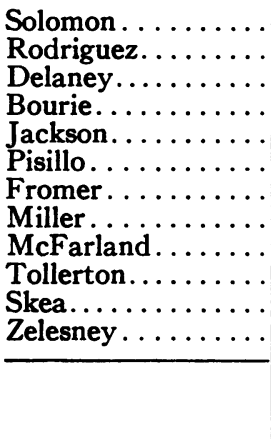 } & $\begin{array}{ll}\text { NE } & 4 \\
\text { NE } & 5 \\
\text { NE } & 6 \\
\text { NE } 10 \\
\text { NE } 13 \\
\text { NE } 14 \\
\text { NE } 15 \\
\text { NE } 17 \\
\text { NE } 18 \\
\text { NE } 19 \\
\text { NE } 20 \\
\text { NE } 21\end{array}$ & $\begin{array}{c}.000004 \\
* \\
* \\
.000050 \\
* \\
* \\
.000004 \\
* \\
* \\
.000004 \\
* \\
*\end{array}$ & $\begin{array}{r}33 \\
50 \\
62 \\
143 \\
71 \\
125 \\
250 \\
100 \\
143 \\
333 \\
250 \\
125\end{array}$ & $\begin{array}{r}33 \\
62 \\
83 \\
143 \\
143 \\
143 \\
333 \\
111 \\
143 \\
500 \\
125 \\
166\end{array}$ & $\begin{array}{l}1.52 \\
1.70 \\
1.80 \\
2.16 \\
1.85 \\
2.10 \\
2.40 \\
2.00 \\
2.16 \\
2.52 \\
2.40 \\
2.10\end{array}$ & $\begin{array}{l}1.52 \\
1.80 \\
1.92 \\
2.16 \\
2.16 \\
2.16 \\
2.52 \\
2.05 \\
2.16 \\
2.70 \\
2.10 \\
2.22\end{array}$ & $\begin{array}{l}.00 \\
.10 \\
.12 \\
.00 \\
.31 \\
.06 \\
.12 \\
.05 \\
.00 \\
.18 \\
-.30 \\
.12\end{array}$ \\
\hline & & & $\begin{array}{c}125 \\
\text { (median) }\end{array}$ & $\begin{array}{c}143 \\
\text { (median) }\end{array}$ & $\begin{array}{c}2.06 \\
\text { (mean) }\end{array}$ & $\underset{(\text { mean })}{2.12}$ & $\begin{array}{l}+.06 \\
\text { (mean) }\end{array}$ \\
\hline
\end{tabular}

* Streptolysin content too low to be titrated.

infecting strains was high. In these cases the absence of a significant rise in antistreptolysin titer was presumably not due to lack of streptolysin. Whether it may be attributed to a weak response of the host is to be considered in detail in the following papers of this series.

Production of skin toxin. Previous studies (1) have indicated that the organisms associated with acute rheumatism are erythrogenic; that is, they produce capillary toxin which causes an erythematous skin reaction when injected intracutaneously into Dick positive individuals or into full-grown Silver Fox rabbits.

The toxin production of the forty organisms was studied by testing the capacity of each filtrate to produce an erythematous reaction. The filtrate was made from a forty-eight hour growth in Difco proteose broth. The skins of two Silver
Fox rabbits which had previously been found to give a $1 \mathrm{~cm}$. reaction to 5 S.T.D. (skin test doses) of Dick toxin were used for each test. Dilutions of filtrate 1:50 and 1:100 were injected intracutaneously. Controls consisted of broth and heated filtrate. When the results were questionable, the filtrates were tested on other animals. The reactions are expressed as follows: no reaction, negative; macular lesion over $1 \mathrm{~cm}$. in diameter, weak; a papular lesion with erythema more than $1.5 \mathrm{~cm}$. in diameter, strong. All readings were made at twenty-four hours. The findings are presented in Table I.

It is seen in Table $I$ that sixteen out of twenty $\mathrm{E}$ strains were strong toxin producers, and in only one instance was this function found lacking. In contrast, of twenty $\mathrm{NE}$ strains only four were strong toxin producers, and in thirteen no 
soluble toxin could be detected. The correlation between intensity of the rheumatic attack and strength of toxin production previously reported (1) seemed to be present in this study.

\section{DISCUSSION}

The relationship between scarlatina and rheumatic fever is an interesting one. Epidemiological observations indicate a similar distribution. In the North Temperate Zone where scarlet fever is prevalent, acute rheumatism is common and severe. In contrast, in tropical environments where scarlet fever is absent (14), acute rheumatism appears to be rare and mild. That streptococcus infection of the tonsils occurs in the tropical environment of Puerto Rico has been shown by Pomales (15). A limited study of Pomales strains has been made by the authors. This small group of organisms did not produce skin toxin, were not pathogenic for young rats and were antigenically different from scarlatinal strains and from organisms effective in initiating rheumatic recrudescences. In an extensive study of hemolytic streptococcus in British Guiana, Grace and Grace (16) have demonstrated that strains of hemolytic streptococcus isolated from abscesses and lymphangitis, either did not produce skin toxin or produced a toxin not neutralizable by scarlatinal antitoxin. These organisms were serologically unrelated to strains obtained from patients with scarlet fever in England and in New York. According to Grace (17) "they differ markedly from the common beta hemolytic streptococcus of temperate climates in morphology, serological reactions and in virulence for man and mice." It is conceivable that the rarity of acute rheumatism in the Tropics and the parallel absence of scarlatinal infection may be due to inhibited activity of Streptococcus hemolyticus as a respiratory pathogen.

Clinicians have long recognized that scarlet fever in children is sometimes followed after a period of weeks by an initial attack of acute rheumatism. Paul et al. (18), studying postscarlatinal rheumatism in New Haven, found " that many examples of post-scarlatinal rheumatism or carditis either represent the lighting up of a previously unsuspected latent or sub-clinical form of rheumatic fever, or represent the manner in which an individual possessed of a "rheumatic diathesis ' may react to scarlet fever." The present authors have observed both initial rheumatic attacks following scarlatina and the development of recrudescences in rheumatic subjects who probably had scarlet fever without a rash (19). These rheumatic patients were infected with organisms that caused scarlet fever in their siblings. ${ }^{6}$

As far as is known, the rheumatic patient only rarely develops the clinical picture of scarlet fever. Hector (20), studying scarlet fever in England, was able to elicit evidence of previous rheumatism in only a few of a large group of scarlatinal patients. A study of the discharge diagnoses of patients at Willard Parker Hospital, New York City, showed that the incidence of mitral stenosis in individuals admitted with scarlet fever was extremely low. Furthermore, although throat infections occur frequently during the winter and spring months, only three times has scarlet fever been seen by the authors ${ }^{2}$ in a group of more than 500 rheumatic children during a period of six years.

The immunological evidence offers a possible explanation for the rarity of scarlet fever in rheumatic subjects. According to the collected statistics of the Pickett-Thomson Research Laboratory (21), approximately 50 per cent of urban school children under fifteen years of age are Dick positive. On the other hand, Swift et al. (22), while studying the reaction to the Dick test in children with rheumatic fever, found that among 112 patients with either active or latent rheumatic fever, only fifteen showed positive reactions.

6 An illustrative example follows: Katherine $H$. and William H., sister and brother, had been under observation in the Vanderbilt Clinic for over two years when both contracted a throat infection on the same day. Katherine, who was known to be a rheumatic subject with mitral stenosis, recovered from pharyngitis and remained symptom-free for ten days. William, who in the past had had neither symptoms nor signs of rheumatism, developed the typical clinical picture of scarlet fever the day after infection of the throat. He was placed in isolation at Willard Parker Hospital. Two weeks later both children developed epistaxes, fever and joint pains. Katherine (History No. 417904) was admitted to Babies Hospital with a rheumatic recrudescence and William (History No. 294788) was admitted to Babies Hospital with his initial rheumatic attack, accompanied by severe carditis.

7 Two cases were followed by pancarditis, the third by mild carditis. 
Kaiser (23), Collis (24) and other workers have likewise observed a low incidence of Dick positive reactions in children with rheumatism. Among the authors' group of rheumatic patients under the age of fifteen, less than 10 per cent were Dick positive, although less than 5 per cent of the group gave a history of having had scarlet fever. The high incidence of Dick negative reactions among rheumatic children who have not had scarlet fever points towards experience with erythrogenic organisms, presumably in the course of frequent throat infections with $\mathrm{E}$ strains. This would account for the rarity of the clinical picture of scarlet fever among children with rheumatic heart disease. The small percentage, less than ten, of Dick positive rheumatic patients corresponds to the 10 per cent of non-rheumatic patients who fail to become Dick negative after scarlet fever.

Finally, there appears to be a close similarity between the type of hemolytic streptococcus associated with scarlatina and rheumatic fever. The organisms recovered from the throats during scarlet fever and the throat strains effective in initiating recrudescences in the rheumatic subject are serologically indistinguishable $(1,25)$. They are both characterized by their capacity to elaborate soluble toxin (1) and streptolysin (13). They both stimulate antibody production in high titer as judged by the antistreptolysin levels developed in individuals recovering from scarlet fever or individuals with acute rheumatism (26). The patient with rheumatic disease is usually Dick negative and fails to develop the rash of scarlet fever when infected with a scarlatinal strain. This was striking in The Pelham Home epidemic, described in preceding papers of this series (27). At that time a highly effective agent $^{8}$ (Strain EpEH, Table I) was found to produce strong scarlatinal toxin, to cause pharyngitis without a rash in rheumatic subjects, and to give rise to a severe outbreak of rheumatic recrudescences.

\footnotetext{
8 The strains from this epidemic fell into our group VI (1), Griffith Type 26 (25). It is possible that the typing of hemolytic streptococcus may help to determine which organisms are highly effective in initiating rheumatic activity.
}

\section{SUM MARY}

The biological characteristics of strains of hemolytic streptococcus associated with acute pharyngitis in rheumatic subjects have been studied.

Half of the strains selected initiated intense activity of the rheumatic process and the other half failed to initiate rheumatic activity in susceptible subjects.

The cultural characteristics of the organisms studied were essentially the same in both groups. All strains were of human type.

The effective organisms were characterized by the capacity to produce strong skin toxins and streptolysins and were indistinguishable from scarlatinal strains of Streptococcus hemolyticus. They gave rise to the development of high titers of antistreptolysin in the subjects infected.

Those strains which failed to produce skin toxin and streptolysin, and did not give rise to the development of high titers of antistreptolysin, were ineffective in activating the rheumatic process.

\section{BIBLIOGRAPHY}

1. Coburn, A. F., and Pauli, R. H., Observations on the biological character of Streptococcus hemolyticus associated with rheumatic disease. J. Exper. Med., 1932, 56, 633.

2. Lancefield, R. C., A serological differentiation of human and other groups of hemolytic streptococci. J. Exper. Med., 1933, 57, 571.

3. Todd, E. W., Further observations on the virulence of hemolytic streptococci, with special reference to the morphology of the colonies. Brit. J. Exper. Path., 1928, 9, 1.

4. Avery, O. T., and Cullen, G. E., The use of the final $\mathrm{H}$-ion concentration in differentiation of Streptococcus hemolyticus of human and bovine types. J. Exper. Med., 1919, 29, 215.

5. Edwards, P. R., The biochemical characters of human and animal strains of hemolytic streptococci. J. Bact., 1932, 23, 259.

6. Avery, R. C., Differentiation of hemolytic streptococci of human and of dairy origin by methylene blue tolerance and final acidity. J. Exper. Med., 1929, 50, 463.

7. Ayers, S. H., and Rupp, P., Differentiation of hemolytic streptococci from human and bovine sources by the hydrolysis of sodium hippurate. J. Infect. Dis., 1922, 30, 388.

8. Holman, W. L., The classification of streptococci. J. Med. Research, 1916, 34, 377.

9. Tillett, W. S., and Garner, R. L., The fibrinolytic activity of hemolytic streptococci. J. Exper. Med., 1933, 58, 485. 
10. Garner, R. L., and Tillett, W. S., Biochemical studies on the fibrinolytic activity of hemolytic streptococci. J. Exper. Med., 1934, 60, 239.

11. Holman, W. L., The value of a cooked meat medium for routine and special bacteriology. J. Bact., 1919, 4, 149.

12. Frobisher, M., Tissue-digesting enzyme (histase) of streptococci. J. Exper. Med., 1926, 44, 777.

13. Todd. E. W., A comparative serological study of streptolysins derived from human and from animal infections, with notes on pneumococcal hemolysin, tetanolysin and staphylococcus toxin. J. Path. and Bact., 1934, 39, 299.

14. League of Nations, Epidemiological Report of the Health Section, 1929, 8, 245.

15. Pomales, A., Bacteriologic study of normal throats, pathological throats and tonsils removed at operation in Puerto Rico. Puerto Rico J. Pub. Health and Trop. Med., 1929, 5, 196.

16. Grace, A. W., and Grace, F. B., Researches in British Guiana, 1926-8. On the bacterial complications of filariasis and the endemic nephritis. Number 3 of the Memoir Series of the London School of Hygiene and Tropical Medicine, 1931.

17. Grace, A. W., Filarial lymphangitis, considered as a mild erysipelas resulting from hypersensitiveness to a B. hemolytic streptococcus of a particular type. Trans. Roy. Soc. Trop. Med. and Hyg., 1934, 28, 259.

18. Paul, J. R., Salinger, R., and Zuger, B., The relation of rheumatic fever to postscarlatinal arthritis and postscarlatinal heart disease-A familial study. J. Clin. Invest., 1934, 13, 503.

19. Stevens, F. A., The occurrence of scarlet fever with- out a rash during epidemic. Proc. Soc. Exper. Biol. and Med., 1926, 23, 346.

20. Hector, F. J., Effects of scarlet fever on rheumatic subjects. Arch. Dis. Child., 1926, 1, 339.

21. Annals of the Pickett-Thomson Research Laboratory, 1930, 6, 103. Williams and Wilkins Company, Baltimore, Md.

22. Swift, H. F., Wilson, M. G., and Todd, E. W., Skin reactions of patients with rheumatic fever to toxic filtrates of streptococcus. Am. J. Dis. Child., 1929, 37, 98.

23. Kaiser, A. D., Skin reactions in rheumatic fever (Birkhaug Test). Studies in 801 persons with the toxic filtrate, produced by the non-methemoglobinforming streptococcus isolated from cases of rheumatic fever. J. Infect. Dis., 1928, 42, 25.

24. Collis, W. R. F., Acute rheumatism and hemolytic streptococci. Lancet, 1931, 1, 1341.

25. Griffith, F., The serological classification of Streptococcus pyogenes. J. Hyg., 1935, 34, 542.

26. Myers, W. K., and Keefer, C. S., Antistreptolysin content of the blood serum in rheumatic fever and rheumatoid arthritis. J. Clin. Invest., 1934, 13, 155.

27. Coburn, A. F., and Pauli, R. H., II. Observations on an epidemic of influenza followed by hemolytic streptococcus infection in a rheumatic colony. J. Exper. Med., 1935, 62, 137.

28. Hadfield, G., Magee, V., and Perry, C. B., The lysis of fibrin by streptococci. Lancet, 1934, 1, 834.

29. Myers, W. K., Keefer, C. S., and Holmes, W. F., Jr., The resistance to fibrinolytic activity of the hemolytic streptococcus with special reference to patients with rheumatic fever and rheumatoid (atrophic) arthritis. J. Clin. Invest., 1935, 14, 119. 